\title{
The Long Carry: Landscapes and the Shaping of British Medical Masculinities in the First World War
}

\author{
Jessica Meyer
}

5-7 October 1915 was a busy period for Frank Ridsdale, a private in the 89th Field Ambulance RAMC(T), serving on the Gallipoli peninsula. Having spent the night of $\mathbf{5}$ October at an advanced aid post dressing men's wounds, he came down for breakfast at the dressing station the following morning before spending the rest of the day flattening roads for ambulance waggons. The next day saw him moving between the Main Dressing Station, the Base, where he was sent to collect supplies, and finally the advanced aid post, where he spent the afternoon attending again to the wounded under shrapnel fire. ${ }^{1}$

The variety of work that Ridsdale undertook over a two-day period was hardly uncommon for a Royal Army Medical Corps (RAMC) ranker, particularly in the midst of a campaign such as the Gallipoli invasion. What is notable throughout the nine volumes of diaries he wrote covering his service from August 1915 through to the spring of 1919, however, is the range of ways in which the varying landscapes he served in

J. Meyer $(\square)$

University of Leeds, Leeds, UK

(C) The Author(s) 2018

S. Daly et al. (eds.), Landscapes of the First World War, https://doi.org/10.1007/978-3-319-89411-9_7 
shaped the work he undertook. On the peninsula, he was both manipulating the landscape through his road levelling, and negotiating it as he moved between base, dressing station and aid post. Later he would find himself similarly occupied in France and Flanders, digging drains to enable a hospital to which he was posted to withstand the rain, and carrying wounded men from aid post to dressing station over periods lasting up to 20 hours. $^{2}$ In both settings, the landscape defined the rigours and challenges of the work undertaken, from the hills on the peninsula, which dictated the location of the base and its distance from the dressing station, to the damaged French landscape which caused Ridsdale to get lost while evacuating the wounded. ${ }^{3}$

The lives of all soldiers in the First World War were shaped, to a greater or lesser extent, by the landscapes in which they served. From staff officers planning strategy to the infantryman living a troglodyte existence in trenches, landscapes were an inherent part of wartime life. The relationship with the landscape varied, however, not only by rank and sector, ${ }^{4}$ but also by branch of service. The perspective of a cavalryman on the obstacles and opportunities presented by the landscape was fundamentally different from that of a tank driver, while a pilot's map of a landscape from the air would be entirely unlike that of a Sapper working in tunnels beneath the earth. It was not only artillery that, as Rudyard Kipling noted, moved 'by the leave o' the ground'. ${ }^{5}$ All military units did, but all did so in significantly different ways.

This chapter explores the particular relationship to the landscape of the RAMC. Their role within the military was unique in a number of ways. In the first place, they were, under the terms of the Geneva Conventions of 1864 and 1906, a neutral unit who were only allowed to carry arms in self-defence. ${ }^{6}$ Their status within the British armed services, therefore, was that of a non-combatant unit. This status had important implications for how RAMC servicemen were perceived by their combatant comrades, many of whom viewed them, at least initially, as 'poultice wallahs'. As George Swindell recalled, the disparaging epithet 'Rob All My Comrades' was in common use by combatant rankers in the early days of his service. ${ }^{7}$ The work of men whose primary purpose was to save lives and bodies rather than kill or damage them was dismissed as unsoldierly further up the chain of command, which viewed the young Corps (formally established in 1898) as not being properly part of the military. ${ }^{8}$ If, as has been noted by a number of gender historians, the soldier formed the hegemonic masculine ideal in wartime British society, ${ }^{9}$ the 
experiences of men like Swindell point to the important qualification that it was combatant servicemen who this society deemed to have achieved dominant masculinity. Despite wearing a uniform and serving under military discipline, the masculinity of the RAMC serviceman was under threat throughout the war from perceptions of physical frailty and associations with the deviant masculinity of the conscientious objector. ${ }^{10}$ This perception of the fragility of RAMC masculinity had important implications for the ways in which men in the Corps constructed and represented their engagement with different types of landscape.

The relationship of these men to the battlefield was not only unique because they operated in it unarmed, however. Significantly their duties on it also had a dual purpose in military terms. The medical services were required to provide both care, in order to ensure the appropriate treatment of men who might return to health, and therefore active service, if treated promptly, and swift evacuation, removing the wounded from a space where they might become obstacles to the actions of the combatant units. This dual role of evacuation and care provision meant that the unit's work revolved around both movement and stasis- the former in the evacuation process, the latter to aid caregiving and the recovery of health and fitness. Both these priorities shaped the relationships of RAMC servicemen with the landscape, requiring them to interact with it in two key ways, through manipulation and negotiation. This chapter considers each of these forms of interaction within the context of two different landscapes, the Western Front and the Egyptian desert. Using the memoirs and diaries of RAMC servicemen, it examines how descriptions of landscape and, the work undertaken within it, were used by these men to construct definitions of medical service which emphasised the physical and emotional labour of their roles. This, in turn, enabled these men to lay claim to a particular subjective space within the landscapes of war, one in which they were comrades in service rather than 'slackers in khaki'.

\section{The Line of Evacuation}

To understand how landscapes shaped the work and identities of RAMC servicemen, it is necessary to examine the logistical and strategic place they occupied. The work of these men took place primarily along the lines of communication which formed part of the chain of evacuation from No Man's Land to hospital. ${ }^{11}$ This stretched across three zones, the 
collecting zone, occupied by the field units, the evacuation zone, corresponding with the Line of Communication ( $\mathrm{LOC}$ ), and the distribution zone, comprising the Base area, Home hospitals and convalescence (Fig. 7.1).

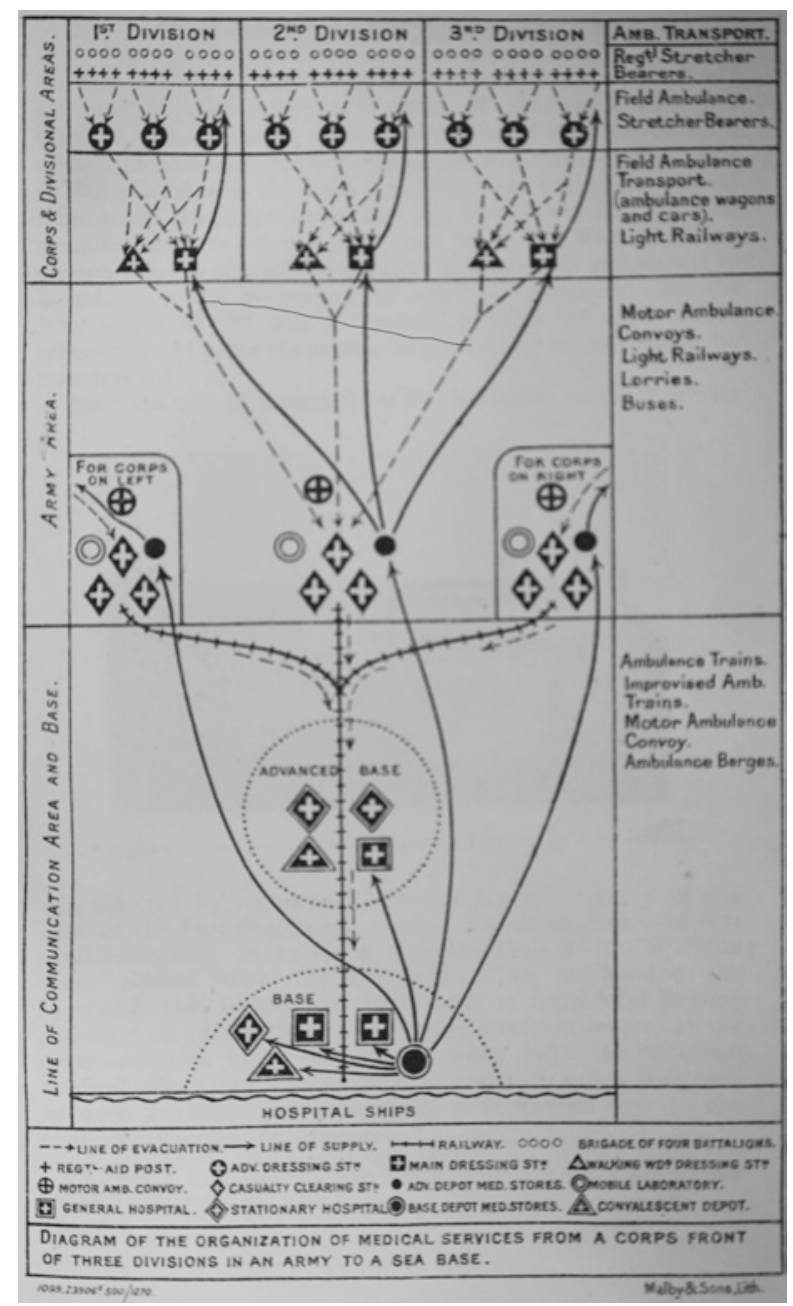

Fig. 7.1 Diagram of the organisation of medical services, W. G. Macpherson, History of the Great War Based on Official Documents: Medical Services General History, Vol. 2 (London: His Majesty's Stationary Office, 1921), 17 
The Royal Army Medical Corps Training manual (1911), which served as the basis for training both officers and men of the Corps, acknowledged the fundamental nature of the relationship between the specialised work of the Army Medical Service (AMS) and the landscape in which they served. For example, specific considerations for the placement of each post along the line of evacuation were laid out in some detail. In the collecting zone, the Regimental Aid Posts (RAPs), the purview of the Regimental Medical Officer (RMO), were the first point of call for wounded men. Here they received the first medical assessment of their wound which was then classified and redressed. ${ }^{12}$ The position of RAPs was decided by the RMO in consultation with the regimental, battalion or divisional commanding officer. It was to be placed 'as far forwards as consistent with reasonable safety. The range of rifle and shellfire and the configuration of the country must be carefully considered'. ${ }^{13}$ Proximity to artillery positions was to be avoided to minimise the chance of the post being hit by enemy fire, although in reality this was nearly impossible as the geography which made a site suitable for an aid post was very similar to that which made it a suitable gun emplacement. Low-lying ground was deemed most suitable as it avoided men having to be carried uphill, and water was often more easily available. Woods were to be avoided as they made dressing stations more difficult for bearers and the walking wounded to find. Nearby water and supplies of straw or grass for the wounded to lie on were desirable, as was a location readily accessible to wheeled vehicles. Ideally, RAPs and dressing stations, the next stop along the evacuation route for wounded men, would be located in suitable buildings. Such buildings should be easy of access; clean or capable of being readily cleaned and prepared for the reception of wounded; possess means of ventilation, and if possible, of lighting, warming, and cooking. Suitability for ready expansion of the dressing station is important'. ${ }^{14}$ Thus, the landscape was called upon to provide protection, accessibility, necessities for the provision of care and the potential for modification as the need arose. In reality, of course, many of these requirements were impossible to meet. RAPs were often little more than dugouts in the front line of trenches, while dressing stations were often exposed, with little access to either necessities of care or space for expansion.

Clearing Hospitals, or Casualty Clearing Stations (CCSs) as they became known after 1915, were the next stage along the line of evacuation. As the pivot 'upon which the removal of the sick and wounded turns' ${ }^{15}$ these were far larger establishments, requiring accommodation in 
suitable buildings or in tents with a minimum camping space of 240 yards by 190 yards to accommodate 200 sick and wounded. As with dressing stations, "the area must permit of great expansion, as a clearing hospital may be required to take in many more sick and wounded'. ${ }^{16}$ CCSs were their own established unit within the RAMC and had always been more static than the dressing stations, set up and run by the tent subdivisions of Field Ambulances. In the early years of the war, they rapidly evolved, as noted by Mark Harrison, into 'semi-permanent fixtures'. From October 1914, 'CCSs gained bedsteads, trained nurses, more surgical equipment, and specialist surgeons. By the end of the year there were eight such units [increased from the original six sent out in August] doing relatively advanced surgical work at the front'. ${ }^{17}$ By 1915 , units could accommodate between 500 and 1,000 patients and their staff consisted of seven medical officers, a quartermaster, a dentist, a pathologist, and seventy-seven other ranks, as well as seven professional nurses from the Queen Alexandra's Imperial Military Nursing Service (QAIMNS). Under the influence of Consulting Surgeon Sir Anthony Bowlby, CCSs became nuclei 'around which a larger surgical organization could be formed'. ${ }^{18}$ Working in pairs from late 1915, CCSs were able to offer forward treatment and care to men suffering from a variety of wounds, including shock, bleeding, lung wounds and soft-tissue injuries. For men with abdominal wounds, where movement dramatically increased the mortality rate, retention and care closer to the front line had an important impact on survival rates. Thus, the increased size of establishment and sophistication of surgery meant that more wounded men both needed to and could be retained for longer, rather than being rapidly evacuated to the base. As a consequence, despite the change of name from hospital to clearing station in 1915 to better reflect their role in the evacuation process, CCSs in fact developed into increasingly static sites of care, a fact which influenced their relationship with the landscapes in which they sat.

\section{Manipulating}

The growing size and stasis of the CCS meant that the landscape increasingly had to accommodate the unit rather than the unit altering to fit the landscape. This was in contrast to the stationary field hospital, the equivalent unit from the Second Anglo-Boer War, which, as Frederick Treves noted in The Tale of a Field Hospital (1912), followed Headquarters, in the case of No. 4 Field Hospital from Chieveley to Spearman's Farm and 
back again. In Treves' memoir, the landscape over which the hospital travelled, and the locations where it established itself, defined the experiences of both travel and care. ${ }^{19}$ While this remained in many ways true for the more mobile medical establishment of the Field Ambulance during the First World War, the existence and strategic centrality of the much larger CCS units brought about a change in the RAMC's relationship with the landscape. While the mobility and flexible structure of the Field Ambulance, formed of three sections, each divided into a bearer and tent subsection, enabled, to some extent, the use of the extant landscape in the setting up of dressing stations, the RAMC increasingly found itself manipulating the landscape to enable it to undertake its dual duties of evacuation and care, the imperatives which coalesced around the role of the CCS.

While RAPs were located in or very near the front line trenches, and dressing stations made flexible use of abandoned buildings and other existing features of the landscape, the location of most CCSs was defined by one of two specific landmarks, with 'most being located at the junction of the collecting and evacuation zones, usually near a railway terminus or the confluence of several roads from the front' ${ }^{20}$ This type of location emphasised the role of the unit as a pivot point for the movement of men along the line of evacuation, a role which required good transport links. While railheads were necessary, navigable roads were equally important, as they allowed men to be brought down from dressing stations by ambulance wagon, and later ambulance car, as well as being transported on further down the line, either by the same method or via ambulance train or hospital barge. The quality of these roads was particularly important for the care of the wounded, with the jolting of poorly-sprung ambulances over badly-maintained roads often proving lethal to men at risk of haemorrhage. ${ }^{21}$

Thus, one of the jobs undertaken by men serving with the RAMC was that of construction. J. W. Upton, a private with the 137th Field Ambulance, was, on one occasion, detailed 'up to the Regimental Aid Post which was practically in the line', not to help care for the wounded there, but to 'dig a place in a bank, to enable a Ford Ambulance car to take shelter whilst waiting for "cases"' ${ }^{22}$ Norman Femor, serving near Albert, found himself undertaking 'a different job for a time helping the Engineers dig a large Dugout with two Entrances. They dug and we carried it all out'. ${ }^{23}$ The $2 / 1$ st London Field Ambulance similarly helped to build the dugout which served as 'B' section's advanced dressing station in Hebuterne in May 1916. ${ }^{24}$ 
It was not only roads and dugouts that RAMC servicemen were called upon to construct, however. Sites of caregiving along the lines of evacuation needed to both move and expand to meet the growing demands placed upon them. As a result, men such as Walter Bentham often found themselves undertaking fatigues such as 'clearing all the wreckage and making a good entrance' to an abandoned building which was to be the winter headquarters of No. 8 Field Ambulance at Hoograff in 1915. ${ }^{25}$ On the Western Front, this sort of repurposing of abandoned or damaged structures, which offered some sort of protection against shellfire, was not only common but often creative. The bearers at the headquarters of the $2 / 1$ st London Field Ambulance, for instance, found themselves, during the Arras offensive, 'located in a deep chalk cave at Wancourt, which certainly provided better shelter than the usually very temporary and unprotected bivouac, but the atmosphere of the cave was-well, to put it mildly-not particularly healthy'. ${ }^{26}$ Not all locations pre-existed, however. As we have seen, CCSs and other large hospital units could be formed of tents covering a large area of land and requiring the installation of amenities such as pathways, incinerators and cookhouses (Fig. 7.2). ${ }^{27}$

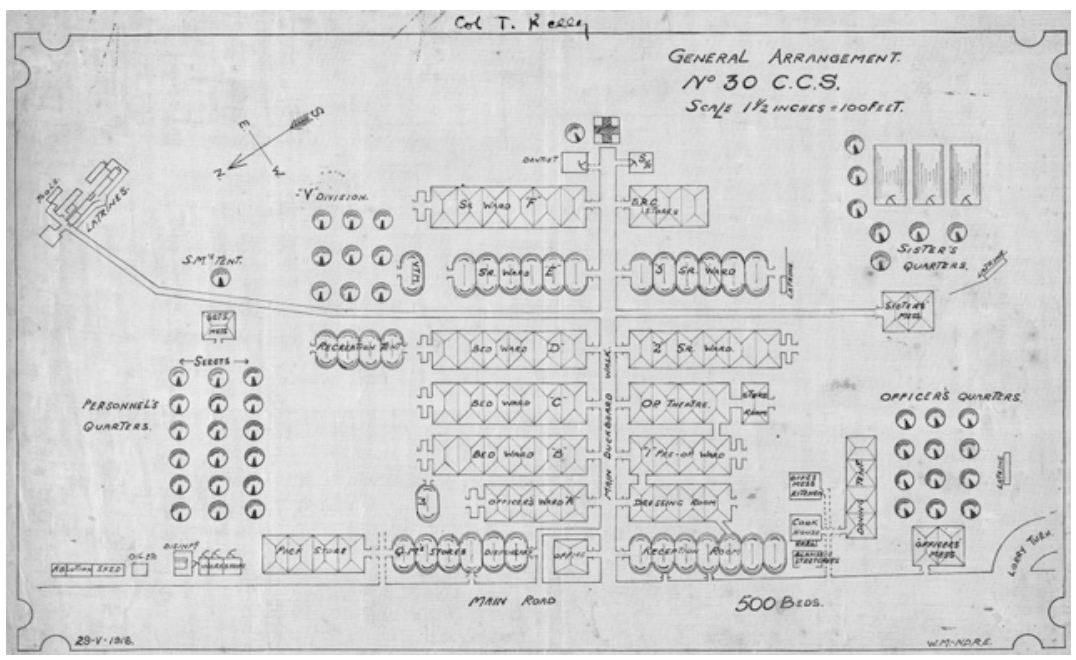

Fig. 7.2 General arrangement of No. 30 CCS, France, Wellcome Images, Wellcome Library, London, L0044173 
In Egypt, drainage was a necessity in an effort to combat mosquitoes. ${ }^{28}$ The comparatively sparse population outside the major conurbations in this theatre meant that tented units were extremely common. As Pt. W. M. Lamb wrote of his time in Palestine, 'Tent pitch and hard work [were often] the order of the day'. ${ }^{29}$ Where possible, the landscape, as in France, was utilised to protect static encampments. Thus, the dressing station that Lamb built on 14 April was 'in a gully, or whadi as it is called here'. ${ }^{30}$ Later, he would find himself serving in a monastery near Jerusalem which had been turned into a hospital. ${ }^{31}$ Like the $2 / 1$ st London Field Ambulance and Bentham, Lamb both utilised and manipulated the landscape in which he found himself. In Egypt and Palestine, as on the Western Front, the work of RAMC servicemen in static sites of caregiving was defined by the need of the units to adapt to the landscape as well as by the labour of shaping the landscape to suit the unit.

While this role as labourer may seem divorced from the medical imperatives of evacuation and care, it was nonetheless significant in structuring RAMC rankers' identities as servicemen. As Rob Thompson has argued, the work of the majority of British servicemen on the Western Front was that of the labourer rather than the soldier. The dominance of daily chores, known in the British military as fatigues, and working parties meant that the work of construction, which shaped many men's civilian lives, was also a significant theme of their military experiences. ${ }^{32}$ In undertaking such manual labour, RAMC servicemen like Upton and Femor were serving in exactly the same way as their combatant colleagues, without arms or killing, but in the service of the national military endeavour. Such service, and the physical labour on which it was based, formed one way in which RAMC servicemen viewed their war work as an appropriately masculine form of service, equal to that of the combatant.

\section{Negotiating}

The equivalence of service between combatant and medical service men has also been identified in the shared experience of trauma that both encountered. ${ }^{33}$ Yet while Lamb wrote that during his time serving in the operating theatre in the monastery he 'saw some dreadful sights', 34 that period of the campaign was, for him, dominated less by the emotional labour of medical care than by a routine of 'putting up camps, receiving wounded then evacuating them by any transport available $[. .$.$] then$ 
moving forward'. ${ }^{35}$ The war of movement that Lamb experienced might appear, on the face of it, very different from the stasis that has tended to define the war, particularly on the Western Front. Yet, as we have already seen, movement was central to the work of RAMC rankers on all fronts. The work of men like Upton in constructing roads and turning places was intended to ease the flow of traffic across the landscape. The process of clearing the battlefield that this enabled was as important a military priority as the movement of troops and supplies. Indeed, it was this process of moving wounded men which most clearly defined the RAMC ranker's, and more particularly the stretcher bearer's, relationship with the landscape. This relationship was, above all, one of negotiation.

The need for the stretcher bearer to negotiate landscapes in order to do his duty was acknowledged from the start of these men's service. The syllabus laid out for training camps in the RAMC training manual included five hours of drill, exercises and lectures related to the removal of the sick and wounded from battlefield to base. ${ }^{36}$ As part of this drill men were to be 'exercised in carrying the loaded stretcher over various obstacles, and taught the methods most suitable for the safe carriage of the patients'. ${ }^{37}$ Exercises were, therefore, to be carried out over 'rough ground' with 'special attention [... being] paid to the carriage of the stretcher so as to keep it level and avoid jolting or unnecessary swaying'. ${ }^{38}$ The Guide to Promotion for Non-Commissioned Officers and Men of the RAMC, a privately produced training manual which summarised the information contained in the official training manual, included a seven-question interrogation of how a stretcher should be carried up and down hill, as well as over uneven ground, with emphasis placed on the fact that, 'under all circumstances' the stretcher should be carried in a horizontal position. This was to be achieved 'by practising the carriage of stretchers over uneven ground until the bearers become trained and habituated to perform this duty with ease and dexterity and comfort to the patient'. ${ }^{39}$ The guide also contains a six-step description of how to carry a loaded stretcher across a ditch, with the emphasis again placed on maintaining the stretcher in as flat a horizontal position as possible under all circumstances. ${ }^{40}$

This, of course, wasn't always possible, as stretcher bearers themselves recalled. C. Midwinter's memoirs of the 32nd Field Ambulance noted that 'carrying in the wounded on Gallipoli, under fire, was terribly hard work. The ground made the going very rough. Stretchers had to be lowered over ledges, steered through narrow paths and thorn bushes'. ${ }^{41}$ 
H. L. Chase's history of the 2/1st London Field Ambulance describes the work of the bearer companies at Ypres in August 1917 as:

an almost overwhelming task [involving] carrying wounded through Sanctuary and Chateau Woods past the Hooge Crater and down the Menin Road, where they were met by the motor ambulances which relieved them of their loads and then sped away down the Menin Road [...] while the bearers returned to the regimental aid posts for more wounded. The carrying track was nothing more than a single line of duckboards winding its way along through a veritable sea of mud, and one false step might well have proved fatal, as was evident from the numbers of drowned men (and horses) who could at intervals be seen almost completely submerged in that dreadful swamp. ${ }^{42}$

George Swindell similarly recalled the effects of weather: 'it was easy carrying wounded on a stretcher, on dry duck-boards, but when the rain had soaked them, and also washed some pieces of mud onto them, it was like trying to walk, $[$ sic $]$ the greasy pole'. ${ }^{43}$

Nor was it only wet that caused problems for stretcher bearers trying to negotiate the landscape. Swindell described one valley he had to travel through as covered with 'earth [which] from the continual explosions, was like breadcrumbs. [... T] here were no dug-outs, or anything in it, the two sides of the valley, were just earth colour, not a bit of colour for hundreds of yards, the shell holes, linked, and over lapped, the whole length'. ${ }^{44}$ Such landscapes made the safe and comfortable transport of patients additionally challenging as a lack of landmarks was deeply problematic for men whose work required 'walking backwards and forwards all day'. ${ }^{45}$ If they were acting as stages in a relay over long distances, they additionally needed to be able to accurately pinpoint where to meet the next company of bearers or the rendezvous with motor ambulances.

The visualisation of landscape was thus an important element to the process of medical evacuation. Stretcher bearers had to be able to identify and note 'ground suitable for moving wounded to or over', ${ }^{46}$ while officers had to be able to evaluate landscapes in order to successfully locate aid posts and dressing stations, as well as communicating these locations and landscapes to those who would need to traverse them. RAMC officer training included military as well as medical training, with lectures on 'the working of the lines of communication, with special reference to the evacuation of the wounded, provision of hospitals, etc., selection of routes for evacuation of sick and wounded, and the 
general principles which regulate their choice' and 'map reading and simple field sketching $[\ldots]$ the object in view being to enable an officer to reach a point indicated by reference to a map, to describe the proposed site of a hospital, etc., or to send in a rough sketch of such things as a dressing station, a hospital site, or a building with its surroundings and approaches, according to the accepted methods'. ${ }^{47}$ For both officers and men, therefore, the ability to evaluate and communicate the landscapes over which evacuation and within which treatment would occur were vital skills.

While the development of these skills in officers via staff training might suggest that these were general medical skills, the ability to evaluate and negotiate landscapes often developed into a specialist one over the course of the war. Delays in the evacuation of the wounded, caused by problems of negotiating landscapes, had significant consequences both for individual wounded men and battlefield logistics. ${ }^{48}$ Yet the shifting nature of the landscape defined the speed of the evacuation process. Bearers used damaged buildings, groups of trees and even dead and rotting corpses as landmarks for their journeys. On the Western Front, as land was fought over and bombarded again and again, this intimate landscape could alter on a daily, or even an hourly basis, affecting men's ability to move through it successfully. Lost bearer units were not uncommon, delaying the speed with which a wounded man was collected and transported successfully to a point where he could be treated, thereby affecting the ultimate success of such treatment. ${ }^{49}$ The bearers of the 6th London Field Ambulance "[r] egularly [...] lost our way [on the Somme], the one and only landmark being High Wood [...]. I recall one journey when my squad toiled for seven solid hours carrying one case from the aid-post near Eaucourt to High Alley'. ${ }^{50}$

If the problems of negotiating landscapes for RAMC servicemen on the Western Front were defined primarily by rain and damage, those in Egypt were similarly shaped by sand and distance. The slipperiness of muddy duckboards was nothing compared to the difficulties of walking through sand with a wounded man as a burden. W. D. Fothergill recalled, 'during our trek across the Sinae Desert [...] being issued with snow shoes as an experiment to see if we could make better progress in the sand-we didn't. We also had sledges drawn by mules to carry the sick and wounded but eventually got Model $\mathrm{T}$ Ford ambulances which ran on "roads" made by laying down ordinary rabbit netting on top of the sand-it worked'. ${ }^{51}$ Charles Ammons also recalled the invention of the 
'wire road' ' $[\mathrm{t}] \mathrm{o}$ ease the movement of vehicles, animals and men in the loose sands $[\ldots]$. This consisted of mesh chicken wire pegged down at the edges and it fulfilled its purpose admirably of keeping wheels and feet on the surface' ${ }^{52}$ Even so, officers such as W. Brown and R. C. Evans spent a great deal of time experimenting with alternative forms of transportation to enable greater ease of evacuating the wounded, including a variety of sleighs and wheeled stretchers, mainly to replace the camel cacolets, detested for their lack of comfort or convenience and their tendency, like the pavé roads of France, to cause further pain and injury to patients transported in them. ${ }^{53}$ Visual negotiation also linked RAMC servicemen's relationships to the landscapes of Egypt and the Western Front. While shelling constantly altered the visual landscape of France and Flanders, making negotiation difficult for stretcher bearers, the featurelessness of the desert had a similar effect in Egypt. The dangers of bearers becoming lost in the landscape were just as great.

In the face of these problems, RAMC stretcher bearers took great pride in their ability to successfully negotiate the landscape during long carries. Swindell recalled numerous cases of men who thanked him for his work in carrying them down, including one man who was:

fifteen stone, some odd pounds, in his skin, and all his clothes muddy, and wet, My he was a weight, turn and turn about we carried him, the further we went in the slithering mud, the heavier he seemed to get, $[\ldots]$ we arrived down at last, he was in a bad way, well thanks mates, the chaps up the line don't half call you some names, I did too, but I didn't know what you had to do, and I withdraw now all I ever said. ${ }^{54}$

Swindell's response to another man who wanted to give him something in return for his labour was 'we don't do our job for that, we do it as our share of this job'. ${ }^{5}$ As with the labour of manipulating the landscape, the effort of negotiating it enabled RAMC servicemen to construct themselves as comrades in service despite the fact that the nature of their service meant that they could not be seen as comrades in arms.

\section{Conclusion}

RAMC servicemen of the First World War served within a variety of landscapes which shaped the nature of the work they undertook. In all these landscapes, however, their work was underpinned by the dual 
priorities of military medical care, to heal the wounded in order to return them to service and to evacuate the battlefield of wounded to facilitate combat. These two potentially conflicting imperatives of stasis and movement meant that medical servicemen's relationships with the landscape were defined by their need to manipulate it and negotiate it. Hospitals where care could be undertaken had to be placed within a landscape which then needed to adapt to the requirements of these sites to expand. The road and rail networks, along which these hospitals were placed, had to be created and maintained to enable the movement of men along the line of evacuation. However, this movement often had to adapt to the landscape, as medical servicemen learned to negotiate mud, sand, ditches and distance without getting lost in order to evacuate their patients.

The labour involved in both manipulation and negotiation was often intense and, for many RAMC servicemen, memorable. Importantly, it enabled them to define themselves as inhabiting appropriately masculine service identities in wartime. The building of hospitals and roads was the equivalent of the manual labour of combatant working parties, while the effort of carrying a wounded man under fire was an alternative form of effortful, even self-sacrificial, service in time of war. The landscapes of war thus shaped not only the roles but also the identities of RAMC servicemen in wartime. Given the centrality of landscape to both the work and character of medical service provision in the British military during the First World War, it is little wonder that landscape should form such a significant element of the records left by these men. It was, for many, the landscape which turned them from 'poultice wallahs' into comrades in service.

\section{Notes}

1. Frank Ridsdale, Diary, 5-7 October 1917, Liddle/WWl/GS/1355, Liddle Collection, University of Leeds.

2. Ridsdale, 13 August 1917, 2 August 1918.

3. Ridsdale, 13 August 1917.

4. Dennis Winter, Death's Men: Soldiers of the Great War (London: Penguin Books, 1978), 80-106.

5. Rudyard Kipling, "Sappers," in The Collected Poems of Rudyard Kipling (Hertfordshire: Wordsworth Editions, 1994), 451.

6. Convention for the Amelioration for the Condition of the Wounded of Armies in the Field, Geneva, 1864, Articles 1 and 2. 
7. George Swindell, In Arduis Fidelus: Being the Story of $4 \frac{1}{2}$ Years in the Royal Army Medical Corps, RAMC 421, Wellcome Library, London, 90.

8. John Blair, In Arduis Fidelis: Centenary History of the Royal Army Medical Corps (Edinburgh: Scottish Academic Press, 1998), 42 and Ian Whitehead, Doctors in the Great War (London: Leo Cooper, 1999), Chapter 1.

9. Lois Bibbings, Telling Tales About Men: Conceptions of Conscientious Objectors to Military Service During the First World War (Manchester: Manchester University Press, 2009), 53; Jessica Meyer, Men of War: Masculinity and the First World War in Britain (Basingstoke: Palgrave Macmillan, 2009), 5-6; and Laura Ugolini, Civvies: Middle-Class Men on the English Home Front, 1914-18 (Manchester: Manchester University Press, 2013), 10.

10. Bibbings, Telling Tales About Men, 89 .

11. W. G. Macpherson, History of the Great War Based on Official Documents: Medical Services General History, Vol. 1 (London: His Majesty's Stationary Office, 1921), 9-10.

12. Most wounded arrived at aid posts with a First Field Dressing on the wound. This would have been applied by the man himself, one of his comrades or one of the regimental stretcher bearers whose duty it was to clear No Man's Land of wounded. None of these men would have had more than a very basic training in first aid and conditions meant that such dressings were usually filthy by the time men arrived at the aid post.

13. War Office, Royal Army Medical Corps Training 1911 (London: His Majesty's Stationary Office, 1915), 113.

14. Royal Army Medical Corps Training, 113.

15. Royal Army Medical Corps Training, 125.

16. Royal Army Medical Corps Training, 125.

17. Mark Harrison, The Medical War: British Military Medicine in the First World War (Oxford: Oxford University Press, 2010), 33.

18. Harrison, 32.

19. Frederic Treves, Tale of a Field Hospital (London: Cassell and Company, 1912).

20. Harrison, The Medical War, 33.

21. Ana Carden-Coyne, The Politics of Wounds: Military Patients and Medical Power in the First World War (Oxford: Oxford University Press, 2014), $55-56$.

22. J. W. Upton, Diary, RAMC 1750, Wellcome Library, London, 8.

23. Norman Fermor, "Personal Experience of an N.C.O. in Charge of Stretcher Squads R.A.M.C. Field Ambulance on the Western Front During World War One Including 12 Miracle Escapes," RAMC 1781, Wellcome Library, London, 5 . 
24. H. L. Chase, The 2/1st London Field Ambulance: An Outline of the 41/2 Years of Service of a Unit of the 56th Division at Home and Abroad During the Great War (London: Morton, Burt \& Sons, 1924), 24-25.

25. Walter Bentham, Diary, 16 September 1915, RAMC 2010, Wellcome Library, London.

26. Chase, The 2/1st London Field Ambulance, 46.

27. Harrison, The Medical War, 36.

28. Harrison, 354-55.

29. William Murray Lamb, Diary, 14 April 1917, Liddle/WWl/GS/912, Liddle Collection, University of Leeds.

30. Lamb, 16 April 1917.

31. Lamb, 24 November 1917.

32. Rob Thompson, "'By the leave o' the ground': The Engineers at Third Ypres," Leeds Legacies of War Seminar Series Video, 1:17:29, posted 9 December 2012, https://www.youtube.com/watch?v=coQ3wTU2ypc, accessed 18 August 2017, 38:15-40:30.

33. Leo van Bergen, Before My Helpless Sight: Suffering, Dying and Military Medicine on the Western Front (Farnham: Ashgate, 2009), 401; Carol Acton and Jane Potter, "These frightful sights would work havoc in one's brain': Subjective Experience and Trauma in First World War Writings by Medical Personnel," Literature and Medicine 30, no. 1 (2012): 61-85; and Carden-Coyne, The Politics of Wounds, 61-9.

34. Lamb, Diary, 24 November 1917.

35. Lamb, 11-15 November 1917.

36. Royal Army Medical Corps Training, 10-11.

37. S.T. Beggs, Guide to Promotions for Non-Commissioned Officers and Men of the Royal Army Medical Corps (London: Gale \& Polden, 1914), 61.

38. Royal Army Medical Corps Training, 211, 221.

39. Beggs, Guide to Promotions, 165-66.

40. Beggs, 166-67.

41. C. Midwinter, 1914-1919 Memoirs of the 32nd Field Ambulance 10th (Irish) Division (Bexleyheath: G. E. Foulger, 1933), 22.

42. Chase, The 2/1st London Field Ambulance, 56.

43. Swindell, In Arduis Fidelus, 95.

44. Swindell, 215.

45. Swindell, 224.

46. Royal Army Medical Corps Training, 9.

47. Royal Army Medical Corps Training, 5-6.

48. Carden-Coyne, The Politics of Wounds, 25-28.

49. Damage to the landscape affected motor transport as well as manual carries. Shell-damaged roads created delays and disruptions and ambulance journeys could be fatal, with poorly-sprung ambulances, many converted 
from private motor cars, and the pavé roads of Northern France and Flanders combining to turn the movement of the evacuation process through the landscape into a painful, and even lethal, experience for the patient. See Carden-Coyne, The Politics of Wounds, 56.

50. 6th London Field Ambulance (47th London Division) History, RAMC 801/20/5, Wellcome Library, London, 2.

51. W. D. Fothergill, Memoir, Liddle/WWI/GS/0575, Liddle Collection, University of Leeds, 4.

52. C. C. Ammons, Service in the First World War, RAMC 1599, Wellcome Library, London, 18.

53. W. Brown, Letters and Diary, 23 February 1917, 28 February 1917, Liddle/WW1/GS/19, Liddle Collection, University of Leeds; Midwinter, 1914-1919 Memoirs, 48.

54. Swindell, In Arduis Fidelus, 149-50.

55. Swindell, 149.

Open Access This chapter is licensed under the terms of the Creative Commons Attribution 4.0 International License (http://creativecommons.org/licenses/ by $/ 4.0 /$ ), which permits use, sharing, adaptation, distribution and reproduction in any medium or format, as long as you give appropriate credit to the original author(s) and the source, provide a link to the Creative Commons license and indicate if changes were made.

The images or other third party material in this chapter are included in the chapter's Creative Commons license, unless indicated otherwise in a credit line to the material. If material is not included in the chapter's Creative Commons license and your intended use is not permitted by statutory regulation or exceeds the permitted use, you will need to obtain permission directly from the copyright holder.

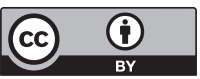

